\title{
ANALISIS MATEMATIS PENGELASAN GREY CAST IRON MENGGUNAKAN PROSES GTAW DENGAN DAN TANPA PREHEAT
}

\author{
Murti Marinah $^{1)}$, Doty Dewi Risanti' ${ }^{2}$, Irwansyah, Detak Yan Pratama ${ }^{3)}$, Asep Suharto ${ }^{4)}$, \\ Muhammad Fadila ${ }^{1)}$ \\ 1,2,3) Departemen Teknik Fisika, Fakultas Teknologi Industri dan Rekayasa Sistem, Institut Teknologi Sepuluh \\ Nopember, Surabaya \\ ${ }^{4)}$ Maintenance \& Utilities Dept. PT. Vale Indonesia TbK, Sorowako \\ Email: risanti@ep.its.ac.id *)
}

\begin{abstract}
ABSTRAK
Pemberian pemanasan awal pada proses pengelasan memberikan efek pengurangan tegangan, distorsi, retakan dan kekerasan pada daerah Heat Affected Zone (HAZ) dengan memperlambat laju pendinginan. Distribusi temperatur saat pengelasan didekati dengan menggunakan persamaan analitik Rosenthal pada logam grey cast iron. Grey cast iron termasuk sulit untuk dilas dan memerlukan perlakuan khusus. Pada penelitian ini, perhitungan distribusi temperatur dan laju pendinginan dibandingkan dengan struktur mikro dan kekerasan untuk grey cast iron yang dilas dengan menggunakan Gas Tungsten Arc Welding (GTAW). Persamaan Rosenthal dengan solusi Bessel hanya cocok untuk distribusi temperatur pada daerah lelehan, sedangkan solusi quasi steady state dapat digunakan untuk prediksi distribusi temperatur arah lateral dan transversal pada logam lasan. Preheating pada suhu $315^{\circ} \mathrm{C}$ berpengaruh pada lebar HAZ yang dihasilkan menurut persamaan eksponensial terhadap travel speed, memperlambat laju pendinginan dan menurunkan kekerasan karena berkurangnya carbon equivalent (CE). Struktur mikro HAZ pada grey cast iron yang diberi preheating menunjukkan dominasi martensit nikel dan eutektik ledeburit, sedangkan tanpa preheating menghasilkan struktur mikro didominasi oleh eutektik ledeburit dan besi karbida dalam white iron.
\end{abstract}

Kata kunci: GTAW, Grey Cast Iron, Persamaan Rosenthal, Preheating, Laju Pendinginan

\section{ABSTRACT}

Preheating in the welding process reduces stress, distortion, cracks, and hardness in the Heat Affected Zone (HAZ) by slowing down the cooling rate. In this study, welding's temperature distribution is approximately using Rosenthal's analytical equation for grey cast iron. Grey cast iron is difficult to weld and requires special precautions. The calculated temperature distribution and cooling rate were compared with the obtained microstructure and hardness for grey cast iron samples welded using Gas Tungsten Arc Welding (GTAW). Rosenthal's equation using Bessel's solution is only suitable for temperature distribution in the melt pool; in contrast, the quasi-steady-state solution can be used to predict the lateral and transverse temperature distribution of the welded metal. Preheating at a temperature of 315 affects the resulting HAZ width according to the exponential equation for travel speed, slows down the cooling rate, and reduces hardness due to reduced carbon equivalent (CE). The microstructure of grey cast iron HAZ, which was given preheating, showed the dominance of nickel martensite and eutectic ledeburite; the microstructure was dominated by eutectic ledeburite and iron carbide within white iron.

\section{Keywords: GTAW, Grey Cast Iron, Rosenthal Equation, Preheating, Cooling Rate}

\section{PENDAHULUAN}

Grey cast iron merupakan besi tuang yang mikrostrukturnya terdiri dari grafit dalam bentuk flake yang berada di dalam matriks ferrous. Secara komposisi biasanya grey cast iron mengandung 2,54\% karbon, 1-3\% silikon dan 0,1-1,2\% mangan. Kekuatan mekanik grey cast iron bergantung pada matriksnya yang mengandung grafit dalam bentuk karbon bebas. Matriksnya dapat berupa ferit hingga perlit dan kombinasi dari kedua fasa tersebut. Grafit flake dalam ukuran yang besar dapat menurunkan kekuatan dan keuletan (Singh, 2016).

Grey cast iron dengan struktur mikro grafit dalam matriks austenit tertransformasi dan sementit bersifat lunak. Flake grafit yang ada di dalam struktur mikronya berbentuk seperti roset dalam 3 dimensi mempunyai densitas rendah yang mampu menahan penyusutan saat proses pengecoran (Singh, 2016).

Flake grafit mempunyai karakteristik peredaman dan machineability yang baik karena grafit bertindak sebagai chip breaker dan melumasi alat potong. Dalam aplikasi yang berhubungan dengan keausan, grafit berguna untuk menjaga pelumasan. Namun demikian grafit bersifat sebagai konsentrasi tegangan yang menurunkan ketangguhan (Singh, 2016).

Pada proses pengelasan pada umumnya, siklus pemanasan dan pendinginan menyebabkan material mengalami ekspansi dan kontraksi, yang menyebabkan tegangan tarik saat kontraksi terjadi. 
Pada saat seperti itu, grafit dalam bentuk flake dapat menyebabkan terjadinya kegagalan. Pada saat proses pengelasan jumlah karbon yang tinggi akan berdifusi ke dalam fasa austenit, membentuk fasa yang keras dan getas yaitu martensit dan karbida pada antarmuka lasan (Bhatnagar \& Gupta, 2016).

Salah satu cara untuk menghindari terbentuknya martensit dan karbida pada lasan adalah dengan mengendalikan laju pendinginan dan komposisi pada daerah lasan melalui pemilihan filler metal yang tepat. Filler dari nikel diketahui dapat mencegah ternentuknya martensit dan karbida (Pouranvari, 2010). Cara lain adalah dengan pemberian preheating. Preheating juga mengurangi residual stress, distorsi, mencegah cold cracking dan menurunkan hardness di daerah heat affected zone (HAZ) (Bhatnagar \& Gupta, 2016).

Sebelumnya telah dilakukan studi eksperimental pengelasan pada nodular cast iron (Laisa, Sulistijono, \& Awali, 2018) dan grey cast iron (Suharto, Risanti, \& Sekartedjo, 2019) dengan menggunakan Gas Tungsten Arc Welding (GTAW). GTAW menghasilkan kualitas las yang baik karena adanya gas pelindung yang mempengaruhi efisiensi termal dan peleburan logam. Penelitian tentang aplikasi las GTAW dengan menggunakan preheating seperti pada (Suharto, Risanti, \& Sekartedjo, 2019) dan (Arifin, 2013).

Faktor yang mempengaruhi perubahan struktur mikro lasan antara lain nilai travel speed. Travel speed yang besar akan memperkecil heat input, dengan demikian cooling rate akan meningkat. Cooling rate berhubungan dengan kekerasan dari lasan, semakin besar cooling rate semakin besar kekerasan yang mengakibatkan material akan menjadi semakin getas (Kumar, Arya, \& Saxena, 2014). Oleh karena itu, pada studi ini akan dilakukan analisis secara matematis proses pengelasan grey cast iron dengan GTAW dengan menggunakan persamaan Rosenthal untuk variasi preheating dan travel speed pengelasan.

\section{METODE PENELITIAN}

\subsection{Material Grey Cast Iron}

Pada studi kali ini, identifikasi masalah dilakukan pada dimensi dan sifat material grey cast iron ASTM A48 Class 40 dengan komposisi pada Tabel 1. Elektroda pengelasan menggunakan ERNi$\mathrm{Cl}$ (Cascade 17T) diameter 3,2 $\mathrm{mm}$ dengan komposisi seperti pada Tabel 1.

Tabel 1. Komposisi kimia material dasar (base metal) dan elektroda lasan yang digunakan (Suharto, Risanti, \& Sekartedjo, 2019).

\begin{tabular}{ccc}
\hline Elemen & $\begin{array}{c}\text { Grey Cast } \\
\text { Iron (wt\%) }\end{array}$ & $\begin{array}{c}\text { Elektroda } \\
\text { (wt\%) }\end{array}$ \\
\hline $\mathrm{C}$ & 5,135 & 0,037 \\
$\mathrm{Si}$ & 1,672 & 0,44 \\
$\mathrm{~S}$ & 0,103 & 0,24 \\
$\mathrm{P}$ & 0,050 & -
\end{tabular}

\begin{tabular}{ccc}
$\mathrm{Mn}$ & 0,672 & 0,24 \\
$\mathrm{Ni}$ & 1,198 & $\mathrm{Bal}$. \\
$\mathrm{Cr}$ & 0,278 & - \\
$\mathrm{Mo}$ & 0,436 & - \\
$\mathrm{Cu}$ & 0,251 & 0,02 \\
$\mathrm{Sn}$ & 0,030 & - \\
$\mathrm{Fe}$ & Bal. & 0,02 \\
\hline
\end{tabular}

Adapun bentuk daerah lasan diilustrasikan seperti pada Gambar 1.

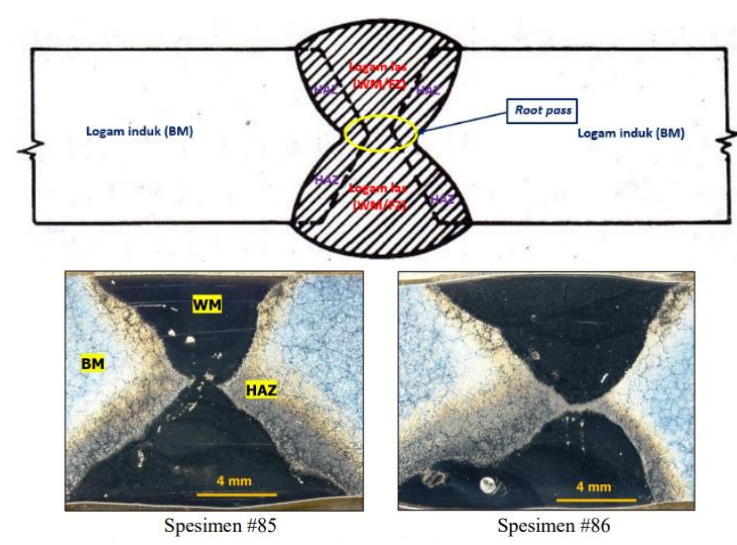

Gambar 1. Ilustrasi daerah heat affected zone (HAZ), weld metal (WM) dan base metal (BM) di sekitar root pass pada sampel \#85 (tanpa preheating) dan \#86 (dengan preheating).

Komposisi pada root pass dan daerah HAZ ditabulasikan pada Tabel 2.

Tabel 2. Komposisi kimia pada root pass dan daerah HAZ yang digunakan (Suharto, Risanti, \& Sekartedjo, 2019).

\begin{tabular}{ccc}
\hline Elemen & $\begin{array}{c}\text { Tanpa preheat } \\
\text { (wt\%) }\end{array}$ & $\begin{array}{c}\text { Dengan } \\
\text { preheat } \\
\text { (wt\%) }\end{array}$ \\
\hline $\mathrm{C}$ & 42,3 & 27,1 \\
$\mathrm{O}$ & 7,53 & 4,9 \\
$\mathrm{Si}$ & 1,06 & 0,44 \\
$\mathrm{Cr}$ & 0,20 & 0,24 \\
$\mathrm{Fe}$ & 47,86 & 63,79 \\
$\mathrm{Ni}$ & 0,47 & 0,72 \\
$\mathrm{Cu}$ & 0,19 & 0,34 \\
$\mathrm{Mo}$ & 0,39 & 1,43 \\
Total & 100 & 100 \\
\hline
\end{tabular}

Perhitungan CE cast iron menggunakan persamaan (Winiczenko, Kaczorowski, \& Skibicki, 2018):

$$
\begin{aligned}
& C E=w_{C}+0,31 \cdot w_{S i}+0,33 \cdot w_{P}+0,45 \\
& w_{S}-0,028 \cdot w_{M n}
\end{aligned}
$$

Berdasarkan persamaan (1), nilai carbon equivalent (CE) dari material dasar, akar lasan dan daerah HAZ dihitung menggunakan data komposisi dari Tabel 2. Hasil perhitungan ditunjukkan pada Tabel 3.

Tabel 3. Nilai CE untuk masing-masing zona lasan dihitung dari pengujian komposisi

Daerah Lasan Nilai CE




\begin{tabular}{cc}
\hline BM & 0,056 \\
WM tanpa Preheat & 0,104 \\
WM dengan Preheat & 0,062 \\
HAZ tanpa Preheat & 0,425 \\
HAZ dengan Preheat & 0,275 \\
\hline
\end{tabular}

\subsection{Model Matematis Yang Digunakan}

Perhitungan untuk distribusi suhu sebelum pemanasan awal dan setelah pemanasan awal dilakukan dengan menggunakan persamaan Rosenthal (Nasiri \& Enziger, 2019) dimana pada kasus pengelasan ini, diasumsikan sumber panas bergerak, sehingga solusi persamaan Rosenthal untuk distribusi temperatur yang dihasilkan oleh sumber panas bergerak dapat dituliskan menurut hukum konservasi energi:

$$
\rho c\left(\frac{\partial T}{\partial t}+v \nabla T\right)=\nabla \cdot(k \nabla T)+\dot{Q}
$$

Jika sumber panas bergerak sepanjang sumbu$\mathrm{x}$, sifat fisika dan distribusi suhu di sekitar sumber panas diasumsikan tetap, maka persamaan (2) dapat dituliskan dalam keadaan quasi-steady state:

$$
\begin{aligned}
& w=x-v t \\
& \frac{\rho c v}{k} \frac{\partial T}{\partial w}=\nabla^{2} T+\frac{\dot{Q}}{k}
\end{aligned}
$$

Menurut asumsi yang digunakan oleh Rosenthal (Rosenthal, 1948) maka solusi umum dari persamaan (3) pada pelat semi tak berhingga menjadi:

$$
T-T_{0}=\frac{\mathrm{q}}{2 \pi \mathrm{kd}} e^{-\frac{v(w+R)}{2 \alpha}}
$$

dimana:

$$
\begin{aligned}
\mathrm{T} & =\text { suhu }\left({ }^{\circ} \mathrm{C}\right) \\
T_{0}= & \text { suhu awal pelat las }\left({ }^{\circ} \mathrm{C}\right) \\
\mathrm{q} & =\text { input daya (Watt) } \\
\mathrm{k}= & \text { konduktivitas termal }\left(\frac{W}{m K}\right) \\
\mathrm{R}= & \text { jarak ke pusat pengelasan }(\operatorname{arc})= \\
& \sqrt{w^{2}+y^{2}+z^{2}} \\
\mathrm{v}= & \text { travel speed }(\mathrm{m} / \mathrm{s}) \\
\alpha= & \text { difusivitas termal material }=\frac{k}{\rho c_{p}} \\
\mathrm{c}_{\mathrm{p}}= & \text { panas spesifik }(\mathrm{J} / \mathrm{kg} . \mathrm{K})
\end{aligned}
$$

Persamaan lain yang digunakan sebagai pembanding adalah persamaan Rosenthal dengan solusi radial quasi-stasioner fungsi Bessel termodifikasi (Nunes, 1983):

$$
T-T_{0}=\frac{\mathrm{q}}{2 \pi \mathrm{kd}} e^{-\frac{v}{2 \alpha} x} K_{0}\left(\frac{\mathrm{v}}{2 \alpha} R\right)
$$

dengan:

$K_{0}=$ Fungsi Bessel orde nol jenis ketiga

$\mathrm{d}=$ setengah dari tebal plat pengelasan (Messler, 2004) $=6 \mathrm{~mm}$

Input daya sendiri didefinisikan sebagai:

$$
q=\eta E I
$$

dengan $\eta$ adalah efisiensi pengelasan, $\mathrm{E}$ adalah tegangan yang digunakan saat pengelasan (volt) dan
I adalah arus yang digunakan saat pengelasan (ampere). Simulasi untuk distribusi temperatur dilakukan dengan menggunakan persamaan (5) dan (6) pada kondisi dengan dan tanpa pemanasan awal $\left(315^{\circ} \mathrm{C}\right)$ serta variasi kecepatan pengelasan antara 0,5 dan $5 \mathrm{~mm} / \mathrm{s}$. Sedangkan untuk input daya, efisiensi arc, arus dan tegangan yang digunakan selama pengelasan ini adalah 0,7 (Stenbacka, 2013), $150 \mathrm{~A}$ dan 14,6 volt (Suharto, Risanti, \& Sekartedjo, 2019), secara berurutan.

Waktu yang diperlukan untuk proses pendinginan pada rentang temperatur $500^{\circ} \mathrm{C}-800^{\circ} \mathrm{C}$ dinyatakan dalam persamaan berikut (Poorhaydari \& Patchett, 2005) (Dong, et al., 2017):

$$
\begin{gathered}
\Delta t_{8-5}=\frac{q / v}{2 \pi \alpha \theta_{1}} \\
\frac{1}{\theta_{1}}=\left(\frac{1}{500-T_{0}}-\frac{1}{800-T_{0}}\right)
\end{gathered}
$$

untuk pelat tebal dan

$$
\begin{aligned}
& \Delta t_{8-5}=\frac{(q / v)^{2}}{4 \pi \alpha c d^{2} \theta_{2}} \\
& \frac{1}{\theta_{2}}=\left(\frac{1}{\left(500-T_{0}\right)^{2}-\left(800-T_{0}\right)^{2}}\right)
\end{aligned}
$$

untuk pelat tipis.

Karakteristik grey cast iron yang digunakan pada perhitungan ditunjukkan pada tabel 4.

Tabel 4. Sifat dari grey cast iron yang digunakan (Kopeliovich, 2012)

\begin{tabular}{cc}
\hline Sifat & Nilai \\
\hline Konduktivitas termal & $53 \mathrm{~W} / \mathrm{mK}$ \\
Density & $7990 \mathrm{~kg} / \mathrm{m}^{3}$ \\
Titik lebur & $1260^{\circ} \mathrm{C}$ \\
Koefisien muai panas & $9 \times 10^{-6} /{ }^{\circ} \mathrm{C}$ \\
Panas spesifik & $490 \mathrm{~J} / \mathrm{kgK}$ \\
\hline
\end{tabular}

\subsection{Metalografi dan Uji Keras}

Metalografi dilakukan pada daerah WM, BM, dan HAZ (Gambar 1) dengan proses grinding dan polishing serta etza dengan larutan nital $\left(5 \% \mathrm{HNO}_{3}\right)$. Kekerasan diukur dengan menggunakan mikro Vickers dengan beban $200 \mathrm{~g}$ dan waktu tahan 10 detik dengan indentor berlian bersudut $136^{\circ}$. Pengukuran kekerasan diambil pada daerah BM, HAZ dan WM, masing-masing sejumlah 6 titik (Tabel 5). Standar deviasi pengukuran kekerasan sebesar 0-72 HV.

Tabel 5. Hasil pengukuran kekerasan pada daerah WM, HAZ dan BM (Suharto, Risanti, \& Sekartedjo, 2019).

\begin{tabular}{llllll}
\hline \multicolumn{3}{c}{ Tanpa preheat } & \multicolumn{3}{c}{ Dengan preheat } \\
\hline WM & HAZ & BM & WM & HAZ & BM \\
\hline 214,7 & 682,8 & 217,2 & 256 & 578,7 & 230,5 \\
\hline
\end{tabular}




\section{HASIL DAN PEMBAHASAN}

\subsection{Hasil Simulasi Variasi Travel Speed Dengan MATLAB}

Hasil Simulasi dengan Matlab menggunakan persamaan (5) dengan data dari Tabel 4 ditunjukkan pada Gambar 2. Dari hasil simulasi terlihat bahwa jangkauan panas dari torch ke logam dasar menjadi semakin luas jika travel speed semakin lambat dan logam diberi prehating. Terlihat pula saat travel speed semakin cepat pola sebaran temperatur berubah dari radial menjadi elipsoid.
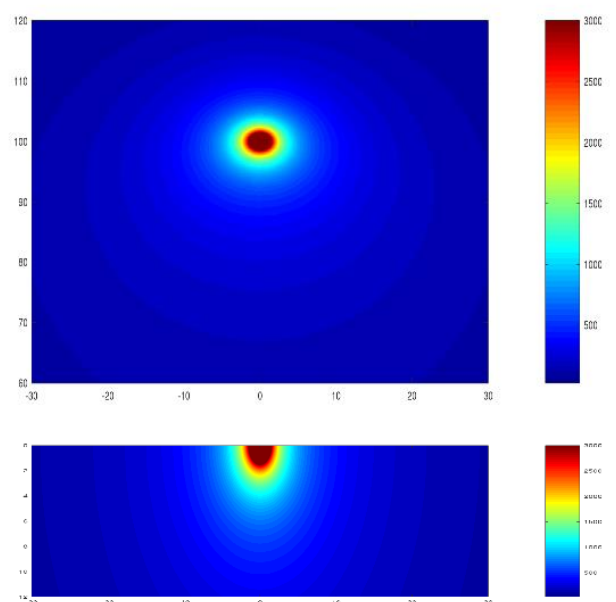

(a)
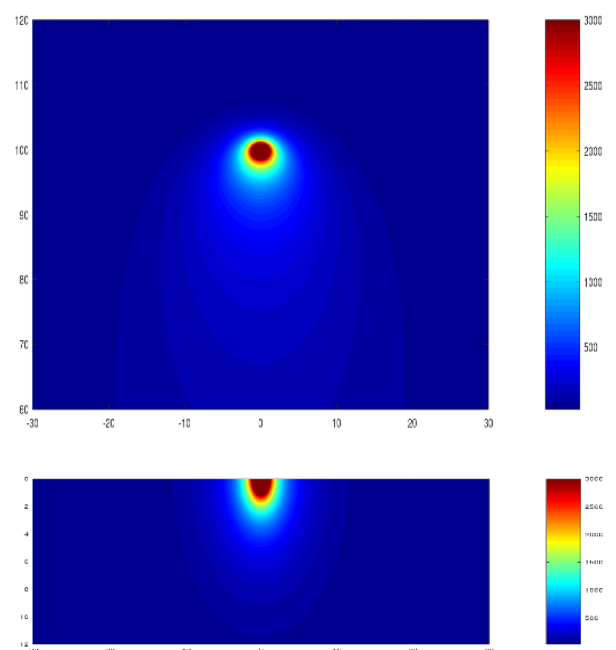

(b)

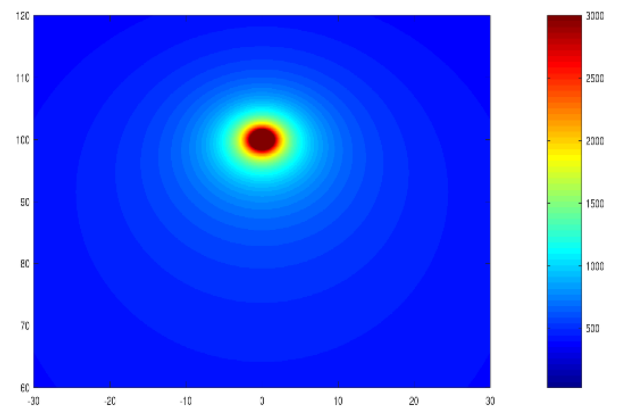

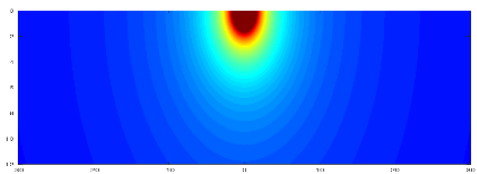

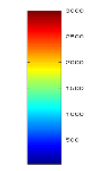

(c)
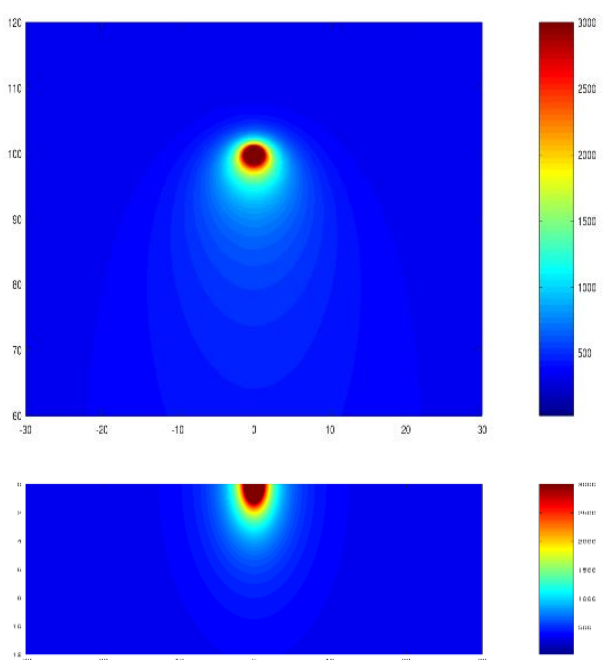

(d)

Gambar 2. Jejak trayektori dari pengelasan dilihat dari atas dan dari penampang dengan kondisi (a) travel speed $=0,5$ $\mathrm{mm} / \mathrm{s}$ tanpa preheating, (b) travel speed $=5 \mathrm{~mm} / \mathrm{s}$ tanpa preheating, (c) travel speed $=0,5 \mathrm{~mm} / \mathrm{s}$ dengan preheating, dan (d) travel speed $=5 \mathrm{~mm} / \mathrm{s}$ dengan preheating.

Gambar 3 berikut ini adalah hasil simulasi dengan menggunakan persamaan (6) untuk kedua kondisi yakni dengan dan tanpa preheating. Nilai difusivitas termal diperoleh dari (Omerod, Taylor, \& Edwards, 1978) untuk cast iron dengan grafit berbentuk flake. Bentuk flake telah diketahui mempunyai karakteristik tersendiri yang menentukan difusivitas termal dari grey cast iron (Hecht, Dinwiddie, \& Wang, 1999). Dari literatur tersebut diperoleh nilai persamaan $\alpha(T)$ :

$$
\alpha=1,504-0,00132 T+1,4884 \times 10^{-7} T^{2}
$$

Dengan demikian untuk tanpa preheat $(\mathrm{T}=25$ $\left.{ }^{\circ} \mathrm{C}\right)$ didapatkan $\alpha$ sebesar 1471 dan dengan preheat ( $\mathrm{T}$ $=315{ }^{\circ} \mathrm{C}$ ) didapatkan $\alpha$ sebesar $1103 \mathrm{~m}^{2} / \mathrm{s}$. Secara umum dari Gambar 3, dapat dilihat bahwa yang paling signifikan berubah terhadap travel speed adalah temperatur puncak dari torch.

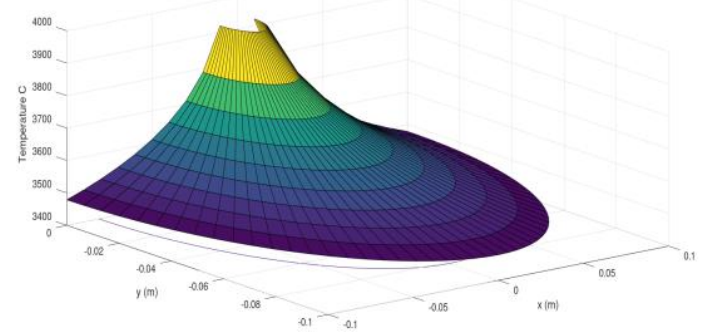


(a)

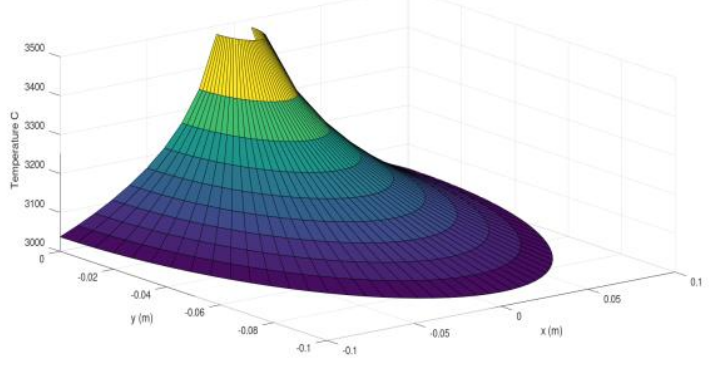

(b)

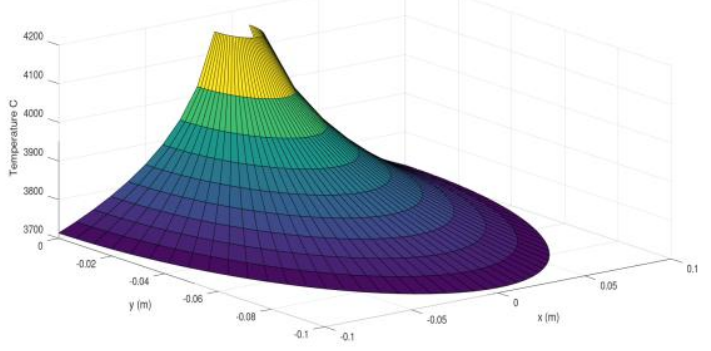

(c)

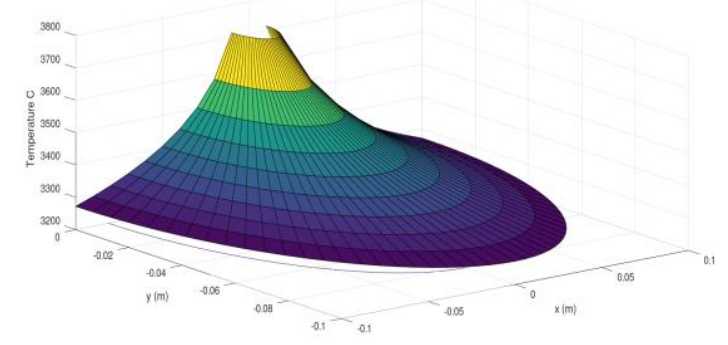

(d)

Gambar 3. Distribusi temperatur pengelasan dengan kondisi (a) travel speed $=0,5 \mathrm{~mm} / \mathrm{s}$ tanpa preheating, (b) travel speed $=5 \mathrm{~mm} / \mathrm{s}$ tanpa preheating, (c) travel speed $=$ $0,5 \mathrm{~mm} / \mathrm{s}$ dengan preheating, dan (d) travel speed $=5$ $\mathrm{mm} / \mathrm{s}$ dengan preheating.

Secara umum semua temperatur puncak pada Gambar 3 berada pada temperatur di atas liquidus (Tabel 4). Solusi menggunakan fungsi Bessel radial yang ditampilkan pada Gambar 3 merupakan distribusi temperatur pada daerah weld metal (WM). Sedangkan Gambar 2 lebih ke solusi daerah HAZ. Preheating bertujuan untuk menstabilkan suhu sampel agar tidak terjadi kerusakan pada saat dan setelah pengelasan akibat adanya thermal shock, pada Gambar 2 dan 3 terlihat bahwa sampel yang diberi preheating menghasilkan temperatur puncak yang lebih tinggi dibandingkan dengan sampel tanpa preheating pada semua nilai kecepatan las. Di samping itu temperatur puncak berkurang dengan semakin besarnya kecepatan las, hal ini berhubungan dengan heat input dari las yang berbanding lurus dengan daya las dan berbanding terbalik dengan dengan kecepatan las (Kutelu, Seidu, Eghabor, \& Ibitoye, 2018) (Gambar 4).

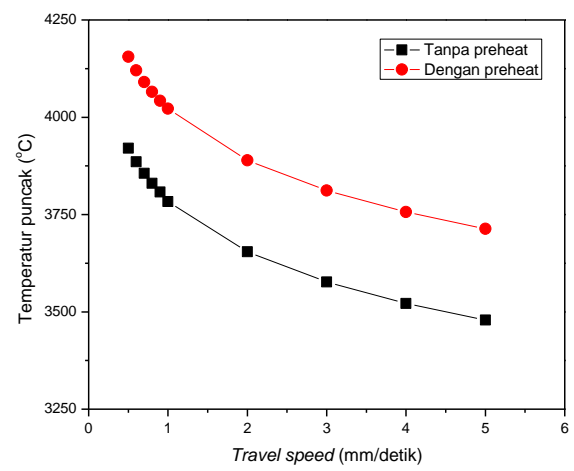

Gambar 4. Distribusi temperatur pengelasan dengan kondisi (a) travel speed $=0,5 \mathrm{~mm} / \mathrm{s}$ tanpa preheating, (b) travel speed $=5 \mathrm{~mm} / \mathrm{s}$ tanpa preheating, (c) travel speed $=$ $0,5 \mathrm{~mm} / \mathrm{s}$ dengan preheating, dan (d) travel speed $=5$ $\mathrm{mm} / \mathrm{s}$ dengan preheating.

Kecepatan las berbanding terbalik dengan luas penampang lasan, kedalaman penetrasi dan lebar lasan. Namun demikan nisbah kedalaman penetrasi terhadap lebar lasan tidak terlalu dipengaruhi oleh kecepatan lasan itu sendiri. Sehingga dapat dikatakan bahwa kecepatan lasan hanya berpengaruh pada volume material yang mencair (Kutelu, Seidu, Eghabor, \& Ibitoye, 2018).

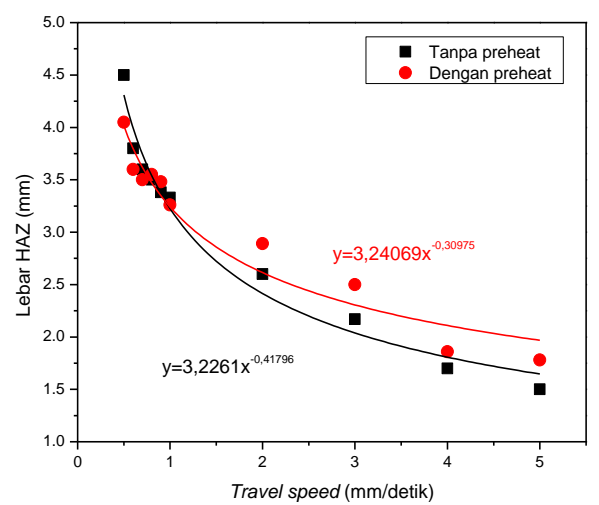

Gambar 5. Pengaruh travel speed pada lebar HAZ untuk kondisi dengan dan tanpa preheat.

Gambar 5 menunjukkan perubahan lebar HAZ yang diukur dari Gambar 2 terhadap travel speed. HAZ di sini merupakan daerah yang temperaturnya di bawah temperatur lebur (Tabel 4) hingga ke temperatur kritis (Poorhaydari \& Patchett, 2005). Pada travel speed yang rendah didapatkan HAZ yang lebar dan terlihat efek preheat tidak signifikan sampai dengan travel speed $1 \mathrm{~mm} /$ detik. Efek preheat menjadi terlihat saat travel speed di atas 1 $\mathrm{mm} /$ detik dengan preheat menghasilkan HAZ yang lebih besar daripada tanpa preheat.

\subsection{Hasil Perhitungan Laju Pendinginan}

Gambar 6 adalah hasil perhitungan laju pendinginan dari temperatur $800-500{ }^{\circ} \mathrm{C}$ dengan menggunakan persamaan (8-11). Laju pendinginan 
ini dapat digunakan untuk prediksi transformasi fasa (Poorhaydari \& Patchett, 2005).

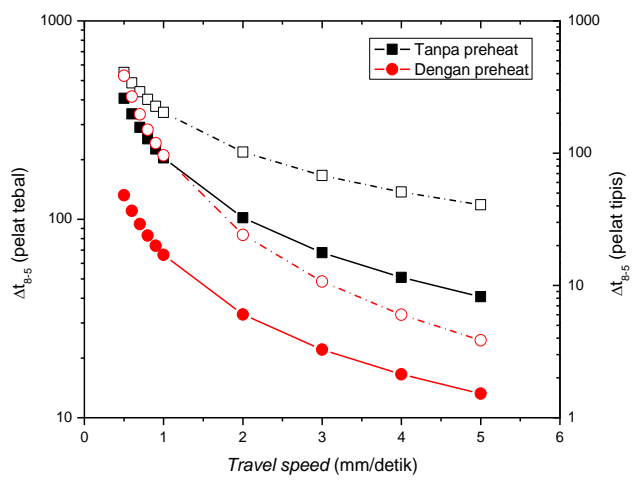

Gambar 6. Pengaruh travel speed pada laju pendinginan dengan simbol penuh untuk pelat tebal dan simbol terbuka untuk pelat tipis.

Dari Gambar 6 terlihat bahwa angka laju pendinginan pada grey cast iron ini untuk asumsi pelat tipis satu orde lebih besar dibandingkan dengan untuk pelat tebal. Preheat secara umum membuat laju pendinginan lebih lambat daripada tanpa preheat. Laju pendinginan pada lasan bersifat tidak homogen dalam arah radial pada penampang melintangnya (asumsi pelat tebal), di sisi lain laju pendinginan lebih cepat pada permukaan atas pelat dekat dengan sisi weld bead (asumsi pelat tipis) daripada di bagian bawah weld bead, oleh karena itu lebar HAZ di permukaan lebih sempit (Gambar 1).

\subsection{Analisis Perubahan Struktur Mikro dan Hasil Uji Keras}

Gambar 7 menunjukkan gambar struktur mikro daerah lelehan (WM). Secara umum struktur mikro grey cast iron tanpa preheat menghasilkan struktur mikro yang lebih kecil dibandingkan dengan preheat. Struktur mikro berupa eutektik ledeburit $\left(\gamma-F e+F e_{3} C\right)$ yang tersusun atas white iron dengan besi karbida dan perlit tanpa grafit untuk tanpa preheat dan dengan sedikit grafit untuk dengan preheat. Terbentuknya grafit dalam bentuk spheroid ini menunjukkan bahwa grafit terbentuk selama proses undercooling ini muncul karena proses pendinginan cepat (Ishida, 1985).

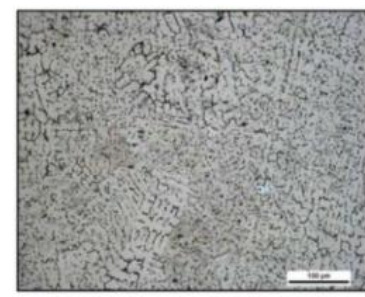

(a)

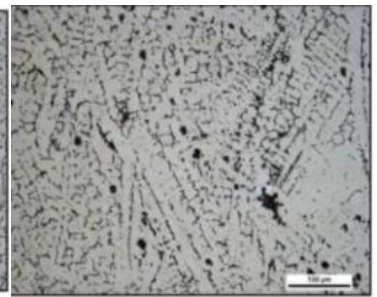

(b)
Gambar 7. Pengaruh preheat pada struktur mikro daerah WM: (a) tanpa dan (b) dengan preheat (Suharto, Risanti, \& Sekartedjo, 2019).

Gambar 8 menunjukkan struktur mikro daerah HAZ. Struktur mikro pada daerah ini tersusun atas ledeburit dan besi karbida, juga terdapat martensit nikel berbentuk seperti jarum dan perlit halus di sekitar batas garis fusi (Ishida, 1985) (Suharto, Risanti, \& Sekartedjo, 2019).

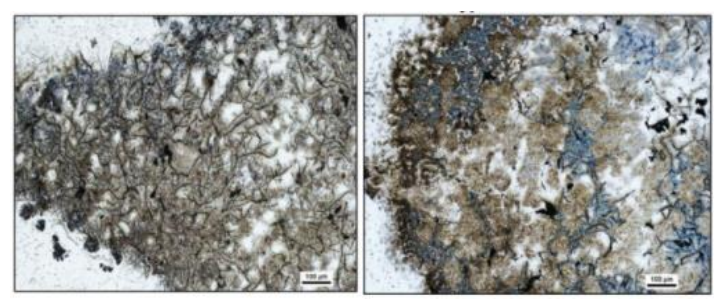

(a) (b)

Gambar 8. Pengaruh preheat pada struktur mikro daerah HAZ: (a) tanpa dan (b) dengan preheat (Suharto, Risanti, \& Sekartedjo, 2019)

Daerah batas antara WM dan HAZ pada Gambar 8 disebut dengan daerah leleh sebagian. Pada daerah ini, terdapat banyak grafit flake. Hal ini dapat membentuk struktur yang rapuh di sepanjang garis fusi las. Matriks austenit yang mengelilingi karbida ini juga dapat berubah menjadi martensit pada suhu yang lebih rendah pada laju pendinginan cepat. Urutan transformasi fasa selama pendinginan daerah batas ini dapat diringkas sebagai berikut (Suharto, Risanti, \& Sekartedjo, 2019):

$$
\begin{array}{r}
L+\text { grafit } \rightarrow \text { eutektik ledeburit }+ \text { austenit } \\
\rightarrow \text { ledeburit }+ \text { martensit } N i
\end{array}
$$

Dari Tabel 3 dan Tabel 5, terlihat bahwa semakin tinggi CE maka kekerasan dari logam juga semakin tinggi. $\mathrm{CE}$ yang diperoleh berhubungan dengan laju pendinginan, yakni: laju pendinginan lambat membuat struktur mikro didominasi dengan reaksi eutektik austenit dan grafit, sedangkan laju pendinginan lambat didominasi oleh austenit dan karbida dalam white iron (Devletian, 1978). Pada penelitian ini, terlihat bahwa keadaan tanpa preheat mengandung lebih tinggi CE dan didominasi eutektik ledeburit dan besi karbida dalam white iron menunjukkan pendinginan lebih lambat. Hal yang sama juga ditunjukkan pada Gambar 6, dimana kondisi tanpa preheat menghasilkan laju pendinginan yang lebih lambat daripada dengan preheat.

Preheating bergantung pada CE pada lasan, ukuran lasan, dan heat input (Devletian, 1978). CE yang tinggi menyebabkan grafitisasi dan feritisasi pada lasan, dengan demikian diperlukan temperatur preheat rendah (atau laju pendinginan yang cepat) untuk mendapatkan kekerasan yang diinginkan. Dari (Devletian, 1978) terlihat bahwa, untuk temperatur preheating $315{ }^{\circ} \mathrm{C}$ diperlukan laju pendinginan kurang lebih $10{ }^{\circ} \mathrm{C} /$ detik, sedangkan pada penelitian ini laju pendinginan sebesar 10 dapat diperoleh jika travel speed dari lasan $>5 \mathrm{~mm} /$ detik (Gambar 6).

\section{KESIMPULAN DAN SARAN}

Dari hasil simulasi dan eksperimen di atas dapat disimpulkan bahwa persamaan Rosenthal dengan solusi Bessel hanya cocok untuk distribusi temperatur pada daerah lelehan, sedangkan solusi quasi steady state dapat digunakan untuk prediksi 
distribusi temperatur arah lateral dan transversal pada logam lasan. Preheating pada suhu $315{ }^{\circ} \mathrm{C}$ berpengaruh pada lebar HAZ yang dihasilkan menurut persamaan eksponensial terhadap travel speed, memperlambat laju pendinginan dan menurunkan kekerasan karena berkurangnya carbon equivalent (CE). Struktur mikro HAZ pada grey cast iron yang diberi preheating menunjukkan dominasi martensit nikel dan eutektik ledeburit, sedangkan tanpa preheating menghasilkan struktur mikro

\section{DAFTAR PUSTAKA}

Arifin, A. (2013). Pengaruh Preheat Terhadap Struktur Mikro, Sifat Mekanis dan Kekuatan Creep Sambungan Las GTAW Material Baja Paduan 12CrlMoV yang Digunakan pada Superheater Boiler. Tesis S2, Teknik Mesin. Jogyakarta: Universitas Gadjah Mada.

Bhatnagar, K. R., \& Gupta, G. (2016). A Review on Weldability of Cast Iron. International Journal of Scientific \& Engineering Research, 7(5), 126-131. https://www.ijser.org/researchpaper/AREVIEW-ON-WELDABILITY-OFCAST-IRON.pdf

Devletian, J. (1978). Weldability of Gray Iron Using Fluxless Gray Iron Electrodes for SMAW. The Welding Journal, 183s-188s. https://app.aws.org/wj/supplement/WJ_197 8_07_s183.pdf

Dong, L.-M., Qiu, X.-B., Liu, T.-Y., Lu, Z.-Y., Fang, F., \& Hu, X.-J. (2017). Estimation of Cooling Rate from $800{ }^{\circ} \mathrm{C}$ to $500{ }^{\circ} \mathrm{C}$ in the Welding of Intermediate Thickness Plates Based on FEM Simulation. Journal of Materials Science and Engineering B, 7(1112), 258-267. https://davidpublisher.org/Public/uploads/C ontribute/5a823c8e65130.pdf

Hecht, R., Dinwiddie, R., \& Wang, H. (1999). The effect of graphite flake morphology on the thermal diffusivity of gray cast irons used for automotive brake discs. Journal of Materials Science, 34, 4775-4781. https://doi.org/10.1023/A:1004643322951

Ishida, T. (1985). A Microstructural Study of Local Melting of Gray Cast Iron with a Stationary Plasma Arc. The Welding Journal, 232s$241 \mathrm{~s}$. http://files.aws.org/wj/supplement/WJ_198 5_08_s232.pdf

Kopeliovich, D. (2012, June 02). Grey cast iron ASTM 40. Retrieved from SubsTech: didominasi oleh eutektik ledeburit dan besi karbida dalam white iron.

\section{UCAPAN TERIMA KASIH}

Penulis mengucapkan terima kasih kepada Departemen Teknik Fisika FTIRS-ITS yang telah mendanai penelitian ini dengan skema Penelitian Dana Departemen Tahun 2019.

https://www.substech.com/dokuwiki/doku. php?id=grey_cast_iron_astm_40

Kumar, R., Arya, K. H., \& Saxena, K. R. (2014). Experimental Determination of Cooling Rate and its Effect on Microhardness in Submerged Arc Welding of Mild Steel Plate (Grade c-25 as per IS 1570). Journal of Material Sciences \& Engineering, 3(2), 1-4. https://doi.org/ 0.4172/2169-0022.1000138

Kutelu, B., Seidu, S., Eghabor, G., \& Ibitoye, A. (2018). Review of GTAW Welding Parameters. Journal of Minerals and Materials Characterization and Engineering, 6, 541-554. https://doi.org/ 10.4236/jmmce.2018.65039

Laisa, M. I., Sulistijono, S., \& Awali, J. (2018). Effect of Heat Input with Current Variation on Weld Overlay GTAW Method with ERNi-CI and ERNiFe-CI Fillers on Mechanical Properties and Micro Structure of Main Cap Product. IPTEK Journal of Proceedings Seried, 4, 33-38. http://iptek.its.ac.id/index.php/jps/article/vi ew/3842

Messler, R. (2004). Principles of Welding: Processes, Physics, Chemistry, and Metallurgy. Singapore: Wiley-VCH Verlag $\mathrm{GmbH} \& \mathrm{Co}$. KGaA.

Nasiri, M., \& Enziger, N. (2019). An analytical solution for temperature distribution in fillet arc welding based on an adaptive function. Welding in the World, 63, 409-419. https://doi.org/10.1007/s40194-018-0667-6

Nunes, A. (1983). An Extended Rosenthal Weld Model: Welding Research Supplement, 165170.

http://files.aws.org/wj/supplement/WJ_198 3_06_s165.pdf

Omerod, J., Taylor, R., \& Edwards, R. (1978). Thermal diffusivity of cast irons. Metals Technology, 5(1), 109-113. https://doi.org/10.1179/mt.1978.5.1.109 
Poorhaydari, K., \& Patchett, B. I. (2005). Estimation of Cooling Rate in the Welding of Plates with Intermediate Thickness. The Welding Journal, $\quad 84(10), \quad$ 149s-155s. https://app.aws.org/wj/supplement/102005-POORHAYDARI-s.pdf

Pouranvari, M. (2010). On the weldability of grey cast iron using nickel based filler metal. Materials \& Design, 31(7), 3253-3258. https://doi.org/10.1016/j.matdes.2010.02.03 4

Rosenthal, D. (1948). The theory of moving source of heat and its application to metal transfer. ASME Trans., 43, 849-866.

Singh, R. (2016). Applied Welding Engineering. Oxford: Butterworth-Heinemann.

Stenbacka, N. (2013). On arc efficiency in gas tungsten arc welding. Soldagem \& Inspeção, $\quad 18(4), \quad 380-390$ http://dx.doi.org/10.1590/S010492232013000400010

Suharto, A., Risanti, D. D., \& Sekartedjo. (2019). On welding gray cast iron using SMAW and GTAW process. AIP Conference Proceedings, 2088, 060002-1-10. https://doi.org/10.1063/1.5095350

Winiczenko, R., Kaczorowski, M., \& Skibicki, A. (2018). The microstructures, mechanical properties, and temperature distributions in nodular cast iron friction-welded joint. $J$ Braz. Soc. Mech. Sci. Eng., 40, 347. https://doi.org/10.1007/s40430-018-1261-y 